\title{
Purple Swamphen or Gallinule (Porphyrio porphyrio) and Humans
}

\section{Forgotten History of Past Interactions}

\section{Ricardo Jorge Lopes}

Cів Io, Centro de Investigação em Biodiversidade e Recursos Genéticos, InBIO Laboratório Associado, Universidade do Porto, Vairão, Portugal riclopes@me.com

\section{Juan Antonio Gomez}

Centro de Recuperación de Fauna "La Granja” El Saler, Generalitat Valenciana, Spain

\section{Alessandro Andreotti}

ISPRA, Istituto Superiore per la Protezione e la Ricerca Ambientale, Ozzano dell'Emilia (во), Italy

\section{Maura Andreoni}

Independent Researcher in Social History of the Ancient World, Via Ameglia 12/2, Genova, Italy

\begin{abstract}
Our knowledge of the historical use of nonhuman animal species in captivity and subsequent human-induced changes in their distribution is poor in comparison to contemporary case studies. Here we assess the hypothesis that, in the case of one waterbird species, the purple swamphen or gallinule (Porphyrio porphyrio), we have neglected the high probability that people transported these birds within the Mediterranean, from Roman to recent times. In ancient iconographies, literary sources, and more recent records there is ample evidence for the use of this species in captivity, captive-breeding, and for trade during several historical periods, especially within the Mediterranean region. All this evidence supports the hypothesis that released or escaped birds might have hybridized with other populations living in the wild. This case study stresses the importance of taking into account past human activity when interpreting contemporary distributional patterns of species.
\end{abstract}




\section{Keywords}

purple swamphen - purple gallinule - Porphyrio porphyrio - human-animal interaction - captive-breeding - trade - history - ornithology

\section{Introduction}

People have a long history of interaction with animals, as providers of food, textiles, transport, power, and other kinds of services (Diamond, 1999; Clutton-Brock, 2012). Certain species have been used for aesthetic purposes and private amusement (e.g., companion animals) or for the pleasure of other people (e.g., circus and zoos), and were regularly kept in captivity and traded. An indirect consequence of this trade has been the accidental or deliberate release of animals, contributing to the spread of these taxa beyond their natural range and hybridization with other subspecies or related species (Kobelt \& Nentwig, 2008; Bertolino, 2009; Blackburn, Lockwood, \& Cassey, 2009). However, only some of these historical interactions and their indirect consequences (e.g., domesticated species) were comprehensively documented while for many others there is little or no documentation (Kalof, 2007). Here we examine the historical evidence for interactions between a species of waterbird and humans, with clear implications for the interpretation of the waterbird's current distribution and population structure.

\section{The Purple Swamphen or Purple Gallinule}

The purple swamphen or purple gallinule (Porphyrio porphyrio) is a waterbird who is widely distributed across Eurasia, Africa and Oceania and is designated as being of "Least Concern" by the IUCN (International Union for Conservation of Nature) (Figure 1). This bird is a large rail, with massive red bill and variable plumage. Most races are predominantly deep blue, with a contrasting blackish or greenish back (Taylor, 1998). The species prefers wetlands and often lives in pairs or larger communal groups, depending on the subspecies and local conditions. The bird's sedentary nature and wide geographical range have favored the formation of isolated populations, with the consequent evolution of distinct subspecies, and some have been proposed as separate species (Taylor, 1996; Taylor, 1998).

Of major concern is the nominate subspecies P. p. porphyrio (Figure 1), which breeds in the western Mediterranean, from the Iberian Peninsula (largest population), France, Sardinia, Sicily, Morocco, and Algeria to Tunisia (Taylor, 1996; Vergara \& Ripoll, 2002). Until recently the bird was designated by the European Union as "Rare," due to a strong decline in range and population size during the 
first half of the 2oth century, mainly due to loss of suitable habitat and excessive hunting (Sánchez-Lafuente, Rey, Valera, \& Muñoz-Cobo, 1992; BirdLife International, 2004). Recently the bird's conservation status was upgraded to "Localised" because in the last three decades the species has increased and expanded beyond its former area, with the help of several reintroduction programs undertaken in the Iberian Peninsula, Balearic Islands, and Sicily (Sanchez-Lafuente, Valera, Godino, \& Muela, 2001; Andreotti \& Ientile, 2004; Pacheco \& McGregor, 2004).
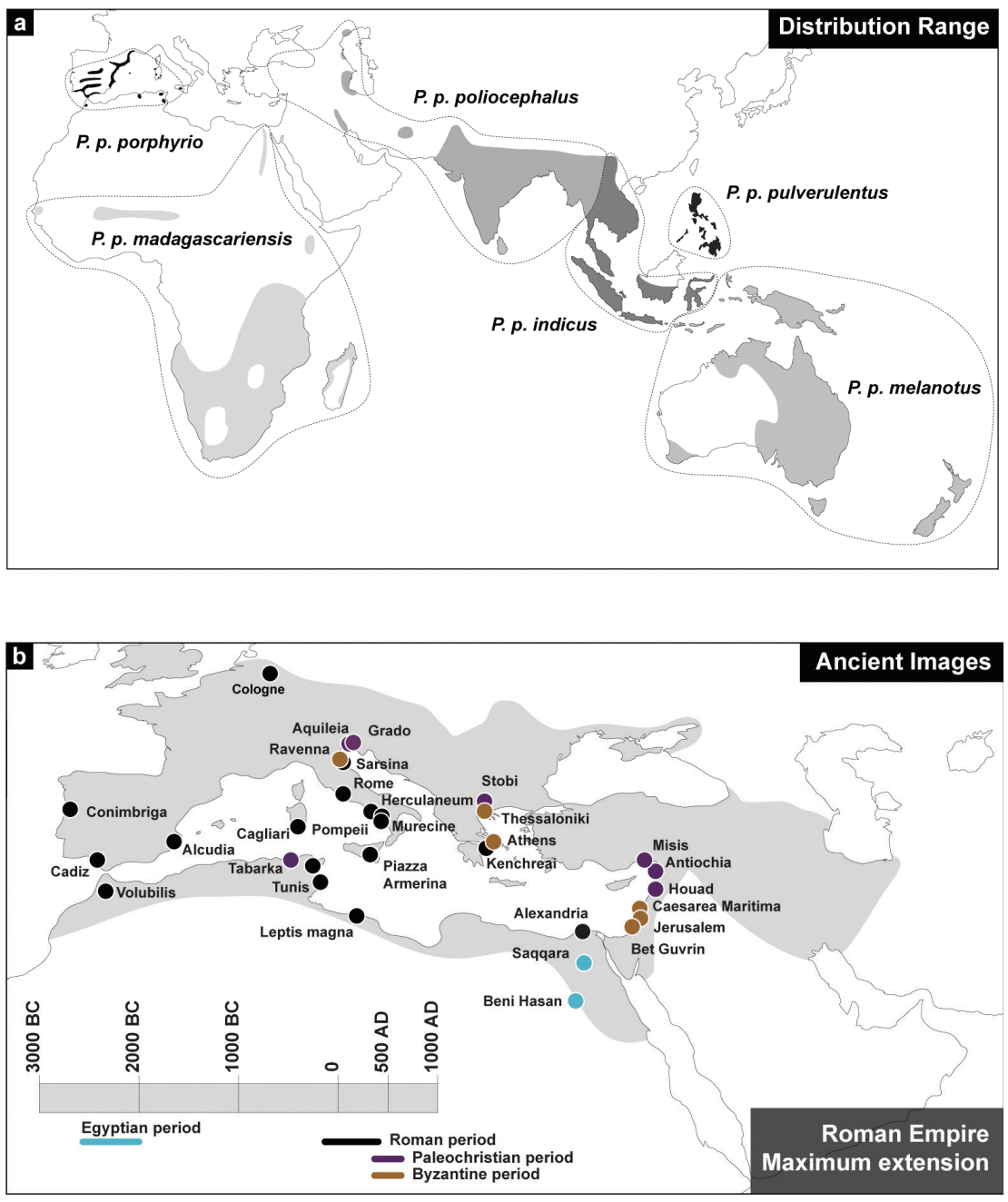


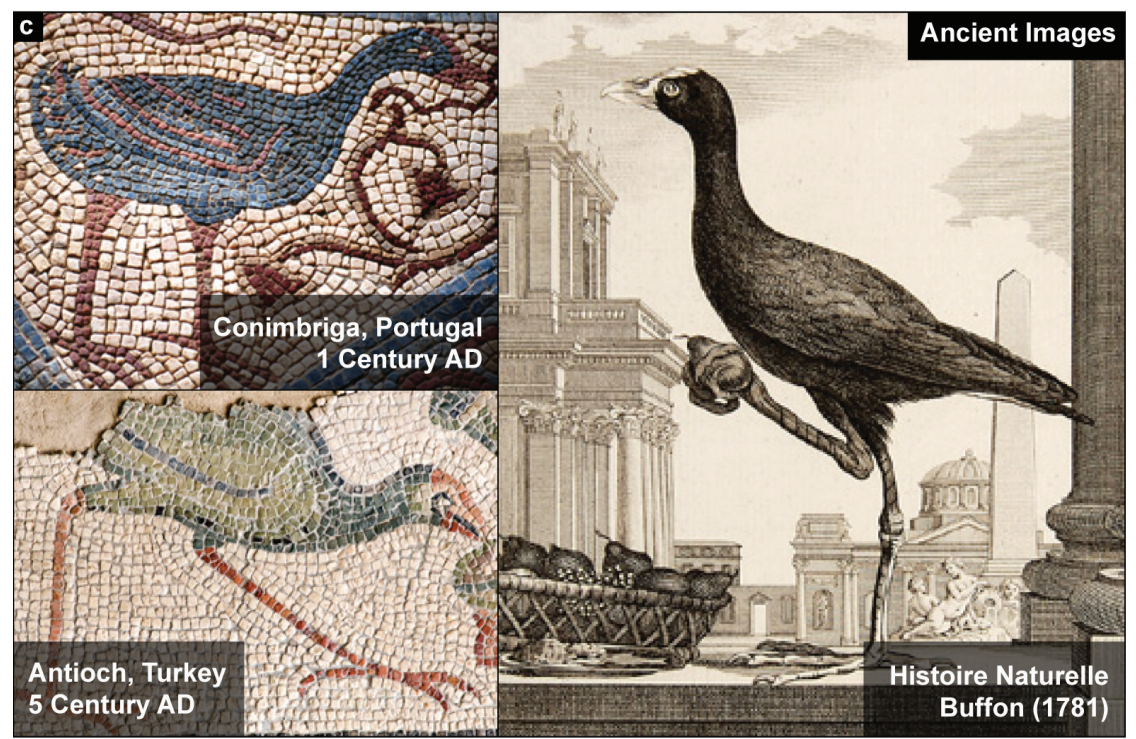

FIGURE 1 (a) Present world distribution of the most recognized complex of subspecies of the purple swamphen, $(b)$ coordinates of the iconographic evidence (see Table 1) compiled in this study, and (c) examples of two mosaics portraying the purple swamphen in different sides of the Mediterranean Sea and from different time periods. The first is a detail of the House of the Fountains floor (1st Century AD) from Conimbriga, Portugal, and the second is a detail from the Ktisis Floor Mosaic (5th Century $A D)$ from Antiochi, Turkey. The lithography depicting the purple swamphen as a companion animal is from Buffon (1781) natural history book.

\section{Past Interactions Assumptions}

These reintroduction programs have confirmed that this species is easily bred in captivity and that their offspring are very tame when reared by people. In contrast, juveniles reared by their parents in captivity show behavioral responses similar to their wild relatives and, when released, they can survive and breed in the wild. Furthermore, our local knowledge of iconographical evidence in Roman archaeological sites near the reintroduction areas allow us to formulate the hypothesis that in the past this species might have interacted quite closely with humans as a captive bird and that this might have promoted the exchange of individuals between different wild populations, as a result of trade and potential escapes back to the wild. This idea was first proposed by Buffon (1781) as early as the 18th century, but no accurate and critical compilation was available to check the ample evidence for this hypothesis. If it is correct, we would expect to find evidence of tameness in captivity, breeding in captivity, and possibly trade, in different periods through time. Therefore, 
the goal of this article is to provide a comprehensive review of this evidence in order to clarify a case to support this hypothesis.

We studied ancient iconographies, literary sources, and more recent bibliographies to find evidence of the use of this species in captivity, captivebreeding, and trade. This was achieved by researching museum collections and archaeological sites with images from the Mediterranean area. Literary sources from ancient Greece and Roman to modern times were investigated for references to this species. Zooarcheological data were also examined. This research was focused mainly on the Mediterranean basin over the last 2,500 years, but it was possible to also highlight similar interactions in other parts of this species' range (e.g., New Zealand). Each record was critically inspected and either accepted or discarded.

\section{Captivity and Captive-Breeding}

Literary sources, from ancient Greece through the Middle Ages to the present day, provide us with convincing evidence that the purple swamphens were often kept in captivity. Furthermore, detailed descriptions of the behavior of the species in captivity suggest they were docile, indicating these were the observations of captive, human-reared birds. From the 7 th century BC onwards, the ancient Greeks associated some species with religious cults and some nonhuman animals were sometimes tame enough to be used in religious processions or kept for educational purposes (Hoage, Roskell, \& Mansour 1996; Jennison, 2005). In the 4th century BC, these collections probably enabled Aristotle to make the first systematic zoological survey called "History of Animals," which describes about 300 vertebrates. The purple swamphen is included and his behavior is described in such detail that it was most probably the result of his observation of captive birds. ${ }^{1}$ The habit of keeping purple swamphens in captivity, not for food but as a companion or even to adorn a temple, is also confirmed by Aristophanes ${ }^{2}$ ( 5 th century BC), Pliny the

1 "... the purple coot is the only one (of the long-necked birds) that swallows water by gulps." In Aristotle (350 BC), History of Animals. Translation: Peck, A. L. (1965), Aristotle Volume IX: History of Animals, Books 1-3. Loeb Classical Library 179. Harvard University Press, Cambridge, Massachusetts.

2 "... and I shall send... against him porphyrion birds... more than six hundred strong"; "... one with a gift of a quail, another with a porphyrion...." In Aristophanes (414 BC), Birds. Translation: Henderson, J. (2000), Aristophanes Volume III: Birds. Lysistrata. Women 
$\operatorname{Elder}^{3}$ (1st century AD), Aelian, ${ }^{4}$ and Athenaeus ${ }^{5}$ (2nd-3rd century AD) (Arnott 2007), from the Greek to the Roman period.

The choice of keeping this bird for these purposes may have several explanations. Aesthetically, this bird has a most appealing image due to the creature's

at the Thesmophoria. Loeb Classical Library 179. Harvard University Press, Cambridge, Massachusetts.

3 "Only the porphyria drinks by beakfuls; it also eats in a peculiar way of its own, continually dipping all its food in water and then using.its foot as a hand with which to bring it to its beak. The most admired variety of sultana-hen is in Commagene (Southeast Turkey); this has a red beak and very long red legs," and "The Balearic Islands send the porphyrio,an even more splendid bird than the one mentionedabove." In Pliny the Elder (77-79 AD), Natural History. Translation: Rackham, H. (1940), Pliny: Natural History, Volume III: Books 8-11. Loeb Classical Library 353. Harvard University Press, Cambridge, Massachusetts.

4 Aelian's work on animals is usually supposed to be taken from other written sources, often Pliny the Elder, but also other authors and works now lost. "The Purple Coot is the most beautiful and the most appropriately named of creatures, and it delights to dust itself, and it also bathes just of pigeons do. But it does not devote itself to the dusting place or to the bath until it has walked a certain number of paces to satisfy itself. It cannot bear being seen feeding, and for that reason it retires and eats in concealment. It is violent in its jealousy and keeps a close watch on the mated female birds, and if it discovers the mistress of its house to be adulterous, it strangles itself.... Yet men take pleasure in it and tend it with care and consideration. And apparently it is either a pet in a sumptuous and opulent household, or else it is admitted into a temple and roams unconfined, moving about as a sacred creature within the precinct." In Aelian (3rd Century AD), On the Characteristics of Animals. Translation: Scholfield, A. F. (1958), Aelian: On the Characteristics of Animals, Volume I: Books 1-5. Loeb Classical Library 446. Harvard University Press, Cambridge, Massachusetts.

5 The author mentions several lost zoological treatises (e.g., Polemon, Callimachus, and Alexander of Myndus) that were the source for stating that this species is common in Libya, held to be sacred, and can be domesticated, also quoting Aristotle. "... Polemon, in the fifth book of his Address to Antigonus and Adaeus, says of the purple coot that when it is domesticated the bird keeps a sharp eye on married women and is so affected if the wife commits adultery that when it suspects this it ends its life by strangling and so gives warning to its master. Polemon adds that the bird does not take food until it has walked round and found a spot suitable to itself; after doing this it rolls in the dust and bathes, and then only does it feed. Aristotle says that it...grasps its food with its feet and breaks it up into small bits; it drinks, however, in gulps... Alexander of Myndus in the second book of Inquiry into Birds says that this bird is Libyan and sacred to the gods which are worshipped in Libya." The author also mentions "... Callimachus, in his treatise On Birds, says ... that the purple coot eats its food burrowing in a dark place, that no one may observe it. For it hates those who approach its food." In Athenaeus (3rd Century AD), Deipnosophistae. Translation: Gulick, C. B. (1929), Athenaeus: The Deipnosophists, Volume III: Books 6-7. Loeb Classical Library 224. Harvard University Press, Cambridge, Massachusetts. 
colors (blue, red, and in some subspecies also green) and his remarkable posture. Additionally, he has several behavior patterns that could be considered anthropomorphic. For example, the delicate way he washes food items and holds his food while eating or the way he avoids been watched while eating, which was already described by Aristotle (see footnote 1). Even in captivity the male shows several display patterns that can be interpreted as signs of fidelity. Thus during courtship he holds weeds in his beak and bows to the female and when breeding the male turns his back to any intruder and stretches his wings in order to appear larger.

While rearing they wash and hold food in their beaks for their chicks whom they protect against intruders. Logistically, as the experience of contemporary captivity-breeding programs shows, this bird is easily kept in captivity and is capable of breeding in trios (two females per male). The chicks become used to human presence and do not escape when reared in gardens or houses. In New Zealand, Guthrie-Smith (1927) advocated the use of purple swamphens as companion animals because of all these characteristics ("... are very human pets... loved to be taken up and have her head and neck tickled..."). Some sources (see footnotes 4 and 5) report a recurring Roman legend, according to which a male starved to death after the death of the female. With this symbolism, purple swamphens became almost a symbol of chastity, watching over women's fidelity, and loyalty in general, and this might have provided another motive for the popularity of this bird among wealthy Romans.

This belief was so famous that it was recollected again in a Renaissance book called Book of Emblems by Alciato, ${ }^{6}$ which had enormous influence and popularity in the 16th and 17th centuries AD. Additionally, another Roman symbol related to the four seasons might have been responsible for their popularity. Seasons had strong symbolism for Romans, with different colors and symbols, well represented in the chariot races, where four major teams called factiones were colored according to the season (Blue, Green, Red, and White). The Blue faction, sometimes symbolized in mosaics and paintings by the purple swamphen, corresponded to autumn and could be the reason the bird was often represented together with grapes (Toynbee, 1973). Interestingly, we did

6 "If the wife in its master's house is unfaithful, the porphyrio despairs and dies of grief. The reason lies hidden in the secrets of nature. This bird may serve as a sure sign of untarnished chastity." The book "is a collection of 212 Latin emblem poems, each consisting of a motto, a picture, and an epigrammatic text." In Alciato, A. (1550), Emblemata. Translation: Knott, B. I. (1996), Alciato Book of Emblems. Scolar Press, Aldershot. 
not find any zooarchaeological data concerning this species. This is perhaps because it is a long-lived animal and its remains migh not have been buried in food waste deposits.

It is quite interesting that most of the sources from the Roman period state that purple swamphens were not used as food, corroborating our interpretation of their relationship with humans. Other animals were often used as food items in sacrifices and public occasions for entertainment or punishment (e.g., parades, menageries, games in the arena, and executions), but the use of animals as companions in ancient Rome is also well documented and was a recurring motif in house decoration (Toynbee, 1973). These motifs show that birds were given more liberty to roam in ancient villas than in modern homes and were an important part of the lives of women and children, who were more confined to domestic environments than men. The capture, shipment and training of animals for public entertainment declined after the 4th century because of changing social attitudes, the influence of Christianity, and logistic reasons. However, household companion animals continued to be quite important in the domestic life of Romans and subsequent cultures.

\section{Ancient Iconographical Evidence}

For all the reasons outlined above, this bird became a motive for many artistic depictions in historical civilizations (Figure 1, Table 1) starting with ancient Egypt (Houlihan, 1996). However, it is only during the Roman period that the largest set of iconographical evidence (mosaics or frescos) is found right across the Roman Empire (Figure 1, Table 1). These show the bird in nature, in gardens, in more domestic environments (e.g., roaming around kitchen tables), or pulling a chariot in circus scenes. Records of this species continued in early Christian mosaics (4th-6th centuries AD), but with different symbolism. In this cultural context, the purple swamphen was often represented perched on the tree of life (a place traditionally occupied by the Peacock, Pavo cristatus), symbolizing the richness of nature, decorating Christian tombs, or even entering Noah's Ark (Toynbee, 1973; Bucci, 2001).

This bird continues to be present in Byzantine and late Roman decorations (Figure 1, Table 1). For example, during the $5^{\text {th }}$ to 6 th centuries AD, we find in Ravenna (Italy), last capital of the Western Roman Empire, many mosaics with a total of 28 representations of this species (Ortali, 1997; Andreoni, 2010). While some of them are depicted as isolated motifs, others like those from San Vitale are shown in their natural habitats. The number of representations is impressive, especially compared to the total number of species (16 species). Interestingly, in one of these mosaics there is a dress decorated with more than twenty purple 
TABLE 1 Iconographical evidence depicting purple swamphen (porphyrio porphyrio) in historical contexts around Mediterranean Sea

\begin{tabular}{lll}
\hline Period & Age & Site (Location) \\
\hline Ancient Egypt & $\sim 25$ oо BC & $\begin{array}{l}\text { Saqqara/Abu Sir, Egypt (Funerary temple of } \\
\text { Userkaf) }\end{array}$ \\
\cline { 2 - 3 } & $\sim 200$ BC & $\begin{array}{l}\text { Beni Hasan, Egypt } \\
\text { (Tomb of Baket III) }\end{array}$ \\
\hline Ancient Rome & 1st cent. BC & $\begin{array}{l}\text { Rome, Italy } \\
\text { (Caesar's horti (?)) }\end{array}$ \\
\cline { 2 - 3 } & 1st cent. AD & $\begin{array}{l}\text { Conimbriga, Portugal } \\
\text { (Different Roman Villae) }\end{array}$ \\
\cline { 2 - 3 } & 1st cent. AD & Cadiz, Spain (Domus) \\
\cline { 2 - 3 } & 1st cent. AD & $\begin{array}{l}\text { Rome/Prima Porta, Italy (Livia's Villa) } \\
\text { 1st cent. AD }\end{array}$ \\
\cline { 2 - 3 } & $\begin{array}{l}\text { Vesuvian area (Pompei, Murecine and } \\
\text { Herculaneum), Italy (Domus del Bracciale d'Oro, } \\
\text { Domus dei Cervi, and Insula Occidentalis) }\end{array}$ \\
\hline
\end{tabular}

1st cent. AD $\quad$ Vesuvian area (Herculaneum), Italy (Domus del
Fauno)

1st-2nd cent. AD Alcudia, Spain (Domus)

2nd cent. AD Alexandria, Egypt (Domus)

2nd-3rd cent. AD Volubilis, Morocco (Domus)

2nd-3rd cent. AD Cologne, Germany (Domus) 


\section{Description}

Limestone relief. Swamp scene, with other waterbirds.

Wall painting. Compilation of local bird life (29 bird species).

Polychrome floor mosaic. Two Purple Swamphens eating snails in a Nilotic scene.

Polychrome floor mosaics. Several P. porphyrio in the corners of hunting scene.

Two birds holding a string.

Polychrome floor mosaic. The bird is represented going towards a plant.

Wall painting. One bird among other species.

Wall paintings. Represented in nature, in gardens, in more domestic environments, or perched upon vegetable candelabra.

Polychrome floor mosaic. Nilotic scene with different other birds.

Black and white floor mosaic. Stylized bird inside a geometrical frame.

Polychrome floor mosaic. Depicted inside one of 8 squares (2 are missing) representing other birds.

Polychrome floor mosaics. A couple of birds pulling a chariot, symbolizing the circus Blue faction.

Polychrome floor mosaics. A couple of birds inside a geometrical panel, pulling a chariot full of grapes, symbolizing the circus Blue faction. 
TABLE 1 Iconographical Evidence Depicting Purple Swamphen (cont.)

\begin{tabular}{|c|c|c|}
\hline Period & Age & Site (Location) \\
\hline \multirow[t]{7}{*}{$\begin{array}{l}\text { Ancient Rome } \\
\text { (cont.) }\end{array}$} & 2nd-3rd cent. AD & $\begin{array}{l}\text { Carthago, El Djem, Oudna, Tunisia (Different } \\
\text { domus and villae) }\end{array}$ \\
\hline & 3rd cent. AD & Sarsina, Italy (Domus) \\
\hline & 3rd cent. AD & Leptis Magna, Libya (Villa) \\
\hline & 4th cent. AD & Cagliari, Italy (Domus) \\
\hline & 4th cent. AD & $\begin{array}{l}\text { Piazza Armerina, Enna, Italy (Villa del Casale) } \\
\text { (Philosophiana) }\end{array}$ \\
\hline & 4th cent. AD & $\begin{array}{l}\text { Kenchreai/Corinth, Greece. Found in their } \\
\text { original packing crates and probably awaiting } \\
\text { installation in a sanctuary of Isis. }\end{array}$ \\
\hline & Unknown & Daphne, Turkey (Domus) \\
\hline \multirow[t]{5}{*}{ Paleochristian } & 4th cent. AD & Aquileia, Italy (Paleochristian basilica) \\
\hline & 4th cent. AD & Stobi, Macedonia (Baptisterium) \\
\hline & 4th-5 th cent. AD & Tabarka, Tunisia Tomb of Pelagius \\
\hline & $5^{\text {th cent. AD }}$ & Antiochia, Turkey (Domus) \\
\hline & $5^{\text {th }}$ cent. AD & Misis, Turkey (Martyrion) \\
\hline
\end{tabular}




\section{Description}

Polychrome floor mosaics. Represented in natural habitat as isolated motive or in fantastic scenes.

Polychrome floor mosaic. Represented inside a geometric motive, forming a frame for a central Dionysus.

Polychrome floor mosaic. In the upper part of the mosaic the bird is listening to Orpheus, together with other animals; in the lower part he is depicted inside one of 6 squares representing different yard animals.

Polychrome floor mosaic. Represented inside a circle, among geometric motives and Solomon knots.

Polychrome floor mosaic. A couple of birds is depicted pulling a chariot, symbolizing the circus Blue faction. The chariot is driven by little aurigae.

Opus sectile. These panels of colored glass represent swamp scenes with different birds and one Purple Swamphen.

Polychrome floor mosaic. The bird is portrayed with other animals.

Polychrome floor mosaic. The bird is perched upon the life tree.

Polychrome floor mosaic. The Purple Swamphen is portrayed in natural habitats, sometimes together with other animals and plants.

Polychrome funerary mosaic. Couple of Purple Swamphens at the feet of the defunct.

Polychrome floor mosaic. The Purple Swamphen and other birds form a naturalistic frame for the central Ktisis (Creation).

Polychrome floor mosaic. The bird is depicted among vegetable scrolls and wine-shoots. 
TABLE 1 Iconographical Evidence Depicting Purple Swamphen (cont.)

\begin{tabular}{|c|c|c|}
\hline Period & Age & Site (Location) \\
\hline \multirow{3}{*}{$\begin{array}{l}\text { Paleochristian } \\
\text { (cont.) }\end{array}$} & $5^{\text {th- } 6 \text { th cent. } \mathrm{AD}}$ & Misis, Turkey Synagogue \\
\hline & $5^{\text {th-6th cent. } \mathrm{AD}}$ & Houad, Lebanon Church of St. George \\
\hline & 6th cent. AD & Grado, Italy Church of St. Eufemia \\
\hline \multirow[t]{6}{*}{$\begin{array}{l}\text { Byzantine/late } \\
\text { antiquity }\end{array}$} & 5 th-6th cent. $\mathrm{AD}$ & $\begin{array}{l}\text { Ravenna, Italy Churches of St. Vitale, } \\
\text { Sant'Apollinare Nuovo, Neonian Baptistery, } \\
\text { Archiepiscopale Chapel }\end{array}$ \\
\hline & $5^{\text {th-6th cent. } \mathrm{AD}}$ & Athens, Greece (Domus) \\
\hline & $5^{\text {th- } 6 \text { th cent. } \mathrm{AD}}$ & Jerusalem, Israel (Domus) \\
\hline & 6th cent. AD & Thessaloniki, Greece Church \\
\hline & 6th cent. AD & Caesarea Maritima, Israel (Domus) \\
\hline & 6th cent. AD & Bet Guvrin, Israel (Domus) \\
\hline
\end{tabular}

NOTE. Any image where the identity of the bird was ambiguous was not compiled.

swamphens. This dress was worn by a lady of the imperial court (betrothed to the Empress's nephew), and the choice of such symbolic decoration could reflect the belief that the bird was supposed to watch over female woman's chastity.

However, some iconographical evidence may not be the result of direct local observations, but the use of models and portable panels, a widespread practice among artists in antiquity (Ling, 1991). This suspicion arises from the fact that some iconographies occur beyond the current range of this species (e.g., mosaics in Cologne, Germany). Nevertheless, since the climate was warmer during the Roman period (Esper et al., 2012), it is also plausible that suitable habitats were 


\section{Description}

Polychrome floor mosaic. Together with other animals, the Purple Swamphen enters the Noah's Arc.

Polychrome floor mosaic. Depicted among vegetable scrolls and wine-shoots.

Polychrome floor mosaic. Depicted inside a circle, among other geometrical motives.

Polychrome wall mosaics. Twenty-eight Purple Swamphens in total, depicted both in their natural habitat or as isolated motive. Purple Swamphen silhouettes are used as decorative element for the ceremonial dress of a lady of the Imperial court.

Polychrome floor mosaic. The bird is depicted isolated, eating a seed.

Polychrome floor mosaic. The Purple Swamphen is inside vegetable scrolls forming a frame to the central Orpheus.

Polychrome floor mosaic. Depicted inside a square frame, among vegetal motives.

Polychrome floor mosaic. The bird is inside vegetable scrolls, among other birds.

Polychrome floor mosaic. The Purple Swamphen is depicted inside a circle, among other birds.

present further north. Even taking into account this bias, what can be reasonably assumed from the evidence compiled is that the purple swamphen was most likely depicted because the bird was very common in the wild and/or in captivity and particularly tame to humans, so that accurate representations could be made.

In contrast, other abundant, colored, conspicuous birds like, for instance, the Flamingo Phoenicopterus roseus, are scarcely represented in some of the most important archaeological sites, such as the area around Vesuvius (Tammisto, 1997), and they are not represented at all in Byzantine Ravenna (Ortali, 1997). Therefore, it is more plausible that the purple swamphen 
representations were modeled from captive birds, and the symbolism surrounding this species (woman's fidelity and seasons) might have been quite important in maintaining his status as an ornamental bird during and after the Roman period.

\section{More Recent Evidence}

We found no written record, illustration or other piece of evidence of purple swamphen from the Middle Ages, even in bestiaries, which suggests the creature lost some popularity and symbolism during this time. During the Renaissance, several books depicted drawings of this species. The bird was often portrayed in the paintings of the Flemish artists Pieter Brueghel the Elder (1525-1569) and his son Jan Brueghel the Elder (1568-1625). The birds are in very accurate behavioral poses and shown in detail (Cano, 2010). They were most probably drawn from captive birds since the region of Flanders is outside the distribution of this species.

Several descriptions of breeding in captivity or close interactions with this species are also available from more recent periods and from different geographical contexts (e.g., Spain ${ }^{7,8}$, Italy ${ }^{9,10}$, and Germany ${ }^{11}$ ) from the 16th to the

"Purple Gallinule ... it's a domestic bird that is reared at home the same way as chickens. Do not need enclosure... and feeds in the ground, picking everything in their way." In Martín Villaverde (1570), Bestiario de Don Juan de Austria.

$8 \quad$ "... when taken alive and brought to our homes... they diligently try to maintain them." In Gaspar de Escolano (1611), Décadas de la Historia de la Insigne y Coronada Ciudad y Reino de Valencia.

9 "... because he eats in captivity fruits, meat and fish" and "The Nesle Marquis brought a pair from Sicilly... we see them in... Catania and Syracuse, often alive in the public places, where they eat leftovers from the fruit and vegetable salesmen." Another example is, "This bird is easy to domesticate and it would be useful and nice to multiply. The pair brought by the Nesle Marquis ... we saw the female building a nest with six eggs." In Buffon (1749-1788), Histoire Naturelle. Paris, France.

10 "... the species is easily domesticated, and in fact may be occasionally seen in a Sicilian poultry-yard, living in perfect harmony with the common barn-door fowl." In Whitaker, J. I. S. (1899), On the Breeding of the Purple Gallinule in Captivity. Ibis, 41(4), 502-505.

11 The example includes an account of trade and breeding in captivity in Central Europe during the 19th century. "They are frequently and in large numbers offered for sale on the European animal market, so that everybody interested can get them. I can warmly recommend them, because their price is very low, keeping them over summer is effortless, and their behavior is much enjoyable. They survive for many years if they are offered a sheltered room or at least a hide in winter, and they breed if they are held in a fenced courtyard or garden." Brehm, A. E. (1867). Illustrirtes Thierleben. Vol. 4. Verlag des Bibliographischen Instituts, Hildburghausen. Page 558. Translation: Mlikovsky, J. (2011). 
20th centuries (Loisel, 1912; Gómez, 2005; Mlikovsky, 2011). For example, in the 18th century, these sources indicated that it was common to see individuals of this species (most likely raised in captivity) feeding on leftovers in markets in Sicily (Buffon, 1781), and in the 19th century in Germany they were common companion animals and could breed in captivity (Mlikovsky, 2011).

It is interesting to note that the subspecies $P$. $p$. melanotus was held in high regard as an elite companion animal in both New Zealand and Samoa, where the bird is called "manuali'i" (literally, "chief's bird"). Red was the prized color of Polynesian aristocracy, and in old Samoa only chiefs could keep such birds (Muse, 1982). Other references refer to their tameness once caught ("it is so tame it will follow its master like a dog") (Kramer, 1995). There is no tradition of purple swamphens being taken as sport game or food, but some references clearly show that this species was used as an ornamental bird at the New Zealand governor's house ${ }^{12}$ (Buller, 1888), and a well-known naturalist from New Zealand reared many individuals and recommended them as companion animals (Guthrie-Smith, 1927). ${ }^{13}$

\section{Trade}

There is evidence for the occurrence of trade of purple swamphens during the Roman period. Pliny the Elder mentions the presence in Italy of birds from the Balearic Islands (Western Mediterranean), in a chapter of his Historia

Records of the Purple Swamphen (Porphyrio porphyrio) from the Czech Republic: A Review. Sylvia, 47, 123-129.

12 This author refers to the legend about the colonization of New Zealand: "[T] have a tradition that tame ones were brought by their ancestors, in their migration from the historic Hawaiki." Buller also refers to the presence of domesticated birds: "I had the pleasure of seeing, in the Government Domain at Auckland, three or four of these birds so thoroughly domesticated that they would readily come at the call of the keeper and take food from his hand." In Buller, W. L. (1888), A History of the Birds of New Zealand. London: Walter Lawry Buller.

13 "[E]very country place in New Zealand, where there are children, should rear a family of Pukeko. They are delightful pets, and pets, moreover, in absolute freedom, who will assert themselves ..." and "Pukekos are very human pets, and do, I believe, really care for their friends, apart from material considerations.... They will come to call, and even if not hailed will follow their friends for notice and recognition, and no doubt all these birds would have been even tamer had it not been necessary to scare them from the house, the verandah and the garden." In Guthrie-Smith (1927), Birds of the Water Wood \& Waste. Wellington: Whitcombe and Tombs Limited. 
Naturalis, where he described the new species that arrived in Italy (see footnote 3). Furthermore, he considers the purple swamphens arriving from the Balearic Islands as "better than the ones" from Comagene (Southeast Turkey). This remark is of great significance, because it supports the hypothesis that birds of different subspecies (see Figure 1) were translocated across the empire.

Also, in New Zealand it is known that the colonization of the islands occurred very recently, in the last millennium (Trewick \& Gibb, 2010). Although most of the evidence points to a natural colonization, some old Maori legends mention purple swamphen as one of the species that was brought with the first Maori people that arrived in New Zealand by boat (Buller, 1888). Additionally, in one 18th Century record from Samoa, a French explorer received as barter more than 300 of these birds (Kramer, 1995).

More recently, in the 19th and 2oth centuries, Mlikovsky (2011) found a large number of records in the wild, in central Europe, of the nominate and madagascariensis (sub-Saharan Africa) subspecies. These records clearly suggest that all were the result of local escapes of traded birds, since the birds were commonly held in a semi-wild state with clipped primaries, and that they often escaped after they regained the ability to fly following molting.

\section{Translocations}

The habit of keeping this species in captivity in several Mediterranean countries led Buffon (1781) to hypothesize that ancient translocations might have had an impact on the current distribution of the purple swamphen. On the basis of unspecified literary sources, he suspected that the Sicilian population originated from some pairs translocated from Africa. Our compilation found evidence of trade between Iberia, Italy, and Turkey, and historical documentation shows that translocation of specimens from different regions was particularly common during the Roman period. An impressive trade of wild animals from Asia and Africa towards Rome and the most important urban centers of the Empire flourished, for instance, to guarantee the presence of wild animals in circuses (Toynbee, 1973).

The 4th century floor mosaics of Piazza Armerina (Sicily) are impressive archaeological evidence of this huge trade, which show the capture and shipping to Italy of a great array of wild animals. Additionally, known translocations also occurred for more common animals and for other purposes, for example, the carp (Cyprinus carpio) from the Danube, who were reared in ponds in Italy and Greece (Balon, 1995), the rabbit (Oryctolagus cuniculus) 
from Iberia to most of western Europe, or the fallow deer (Dama dama) from the Eastern Mediterranean to western Europe (Woodford \& Rossiter, 1994; Davis \& MacKinnon, 2009). Interestingly, Pliny mentions the translocation of a species of croaking frogs from the continent to Cyrene (Libya) to liven up the local frogs who were described as dumb (Pliny, 1940). This reveals another side of the practical and objective rationale that Romans used to face problems with biodiversity.

Contemporary records suggest that purple swamphens born in captivity and released into the wild-either due to conservation actions or to accidental releases - can easily survive and breed, giving rise to self-sustaining populations. In the Mediterranean region, three reintroductions have been successfully carried out in Spain (Valencia), Portugal (Coimbra), and Italy (Sicily), through the release of juveniles born in captivity (Pacheco \& McGregor, 2004). Moreover, the accidental escape of captive birds was responsible for feral populations outside their original range (Fraticelli, 200o; Pranty, Schnitzius, \& Lovell, 2000; Mlikovsky, 2011). For instance, in central Italy some birds ascribed to the oriental race P. p. poliocephalus have been breeding since the 1970 in a small wetland near a private zoo, from which they had been released (Fraticelli, 2000).

The most impressive colonization of new areas occurred in Florida, where escaped birds of the same race started breeding in 1996 as a result of the escape of traded specimens. The introduced population is now so abundant that it is considered a pest (Pranty, Schnitzius, \& Lovell, 2000). These new populations show a key aspect of the process of expansion of purple swamphens, which once established by a small number of founders, can prosper and adapt to new niches of suitable wetland habitat with positive consequences for the species distribution. This can be followed by changes in the social organization that in some populations changed from territorial monogamous pairs to a communal system (Taylor, 1998).

\section{Hybridization between Subspecies}

In the Mediterranean Basin, at least three subspecies occur and it is possible, based on the evidence already described, that miscegenation might have occurred. In experimental conditions the oriental race P. p. poliocephalus produced fertile hybrids when crossed with either the Western Mediterranean P. p. porphyrio or African P. p. madagascariensis (McCarthy, 2006). Therefore, exotic, established populations had the potential to crossbreed 
within Mediterranean populations and hybridize. This might have had a positive (e.g., increase of genetic diversity) or negative (e.g., competition, diseases) impact on the endemic populations.

\section{Conclusions}

This review compiles much of evidence that confirms a very close interaction between man and the purple swamphen, especially in Roman times. The birds were commonly kept and most probably bred in captivity and some were almost certainly traded. This pattern is not exclusive from this time period and further evidence was found in more recent periods (16th-2oth centuries). We also provide evidence to support the hypothesis that ex-captive birds might have founded new wild populations in the past, eventually crossbreeding with local populations. This evidence provides a completely new perspective upon our understanding of the population structure and distribution history for what is usually considered a rare and completely wild species. Testing the magnitude of this effect is our next goal. To this end we are now sampling natural populations in order to assess their genetic diversity (Lopes et al., in preparation).

\section{Acknowledgments}

Particularly we thank Hichem Azafzaf of the Association "Les Amis des Oiseaux" (Tunisia), who gave detailed information for North Africa; Prof. Francesca Cenerini of the Department of Ancient History of the University of Bologna (Italy), who enthusiastically supported this research since its beginning giving support and valuable suggestions; the many reviewers of early drafts, including Albano Beja-Pereira and Carlos M. Pimenta; and Simon J. M. Davis, Nicolle Mode, and Stephen Sabatino for the comprehensive last revision. Permission for the reproduction and authorization for the use of the Conimbriga and Antioch mosaics were obtained, respectively, from the "Museu Monográfico de Conimbriga," Portugal, and Worcester Art Museum, Worcester, Massachusetts. The excavation of Antioch and Vicinity was funded by the bequests of the Reverend Dr. Austin S. Garver and Sarah C. Garver, 1936.35. R. J. Lopes was supported by FCT (Fundação para a Ciência e Tecnologia) Individual Grants SFRH/BPD/40786/2007 and SFRH/BPD/84141/2012, funded by FCT/MEC and POPH/QREN/FSE. 


\section{References}

Andreoni, M. (2010). Il Pollo sultano nei mosaici di Ravenna. Il Carrobbio, XXXVI, 15-22.

Andreotti, A., \& Ientile, R. (2004). La reintroduzione del Pollo sultano (Porphyrio porphyrio) in Sicilia (Aves Rallidae). Il Naturalista Siciliano, 28(1), 599-603.

Arnott, W. G. (2007). Birds in the Ancient World from A to Z. London: Routledge.

Balon, E. K. (1995). Origin and domestication of the wild carp Cyprinus carpio: From Roman gourmets to the swimming flowers. Aquaculture, 129, 3-48.

Bertolino, S. (2009). Animal trade and non-indigenous species introduction: the worldwide spread of squirrels. Diversity and Distributions, 15(4), 701-708.

BirdLife International. (2004). Birds in Europe: Population estimates, trends and conservation status. Cambridge, U K: BirdLife International.

Blackburn, T. M., Lockwood, J. L. \& Cassey, P. (20o9). Avian Invasions, the Ecology and Evolution of Exotic Birds. Oxford: Oxford University Press.

Bucci, G. (2001). L'albero della vita nei mosaici pavimentali del Vicino Oriente. Bologna: University Press.

Buffon, G. L. (1781). Histoire Naturelle, Générale et Particulière, avec la description du cabinet du roi. Paris, France: L'Imprimerie Royale.

Buller, W. L. (1888). A History of the Birds of New Zealand. London: Walter Lawry Buller. Cano, J. G. (2010). Las aves en el Museo del Prado. Madrid: SEO/BIRDLIFE.

Clutton-Brock, J. (2012). Animals as domesticates: A world view through history. East Lansing, MI: Michigan State University Press.

Davis, S., \& MacKinnon, M. (2009). Did the Romans bring fallow deer to Portugal? Environmental Archaeology, 14(1), 15-26.

Diamond, J. M. (1999). Guns, Germs, and Steel: The Fates of Human Societies. New York: W. W. Norton \& Company.

Esper, J., Frank, D. C., Timonen, M., Zorita, E., Wilson, R. J. S., Luterbacher, J., Buntgen, U. (2012). Orbital forcing of tree-ring data. Nature Climate Change, 2(12), 862-866.

Fraticelli, F. (200o). L'introduzione del Pollo sultano asiatico Porphyrio porphyrio poliocephalus nel Lazio. Alula, viI (1-2), 71-73.

Gómez, J. A. (2005). El factible pasado doméstico del calamón. Un ave ornamental en tiempos de los romanos? Quercus, 230, 14-19.

Guthrie-Smith, H. (1927). Birds of the Water, Wood \& Waste. Wellington: Whitcombe and Tombs Limited.

Hoage, R. J., Roskell, A., \& Mansour, J. (1996). Menageries and Zoos to 19oo. In R. J. Hoage \& W. A. Deiss (Eds.), New Worlds, New Animals: From Menagerie to Zoological Park in the Nineteenth Century (pp. 8-18). Baltimore: Johns Hopkins University Press.

Houlihan, P. F. (1996). The Animal World of the Pharaohs. Cairo: The American University in Cairo Press. 
Jennison, G. (2005). Animals for show and pleasure in Ancient Rome. Philadelphia: University of Pennsylvania Press.

Kalof, L. (2007). Looking at animals in human history. London: Reaktion Books.

Kobelt, M., \& Nentwig, W. (2008). Alien spider introductions to Europe supported by global trade. Diversity and Distributions, 14(2), 273-280.

Kramer, A. (1995). The Samoa Islands. Honolulu: University of Hawai'i Press.

Ling, R. (1991). Roman Painting. Cambridge: Cambridge University Press.

Loisel, G. (1912). Histoire des Ménageries de l'antiquité a nos jours. Paris: Octave Doin et Fils.

McCarthy, E. M. (2006). Handbook of Avian Hybrids of the World. Oxford: Oxford University Press.

Mlikovsky, J. (2011). Records of the Purple Swamphen (Porphyrio porphyrio) from the Czech Republic: A review. Sylvia, 47, 123-129.

Muse, C. (1982). The birds and birdlore of Samoa. Walla Walla, WA: Pioneer Press.

Ortali, A. (1997). Gli uccelli nei mosaici bizantini. Ravenna: Edizioni del Girasole.

Pacheco, C., \& McGregor, P. K. (2004). Conservation of the purple gallinule (Porphyrio porphyrio L.) in Portugal: Causes of decline, recovery and expansion. Biological Conservation, 119(1), 115-120.

Pliny. (1940). Pliny-Natural History (Volume 3, Books 8-11, H. Rackham, Trans.). Cambridge, MA: Loeb Classical Library, Harvard University Press.

Pranty, B., Schnitzius, K., \& Lovell, H. W. (2000). Discovery, distribution, and origin of the Purple Swamphen (Porphyrio porphyrio) in Florida. Field Naturalist, 28, 1-11.

Sánchez-Lafuente, A. M., Rey, P., Valera, F., \& Muñoz-Cobo, J. (1992). Past and current distribution of the purple swamphen Porphyrio porphyrio L. in the Iberian Peninsula. Biological Conservation, 61, 23-30.

Sánchez-Lafuente, A. M., Valera, F., Godino, A., \& Muela, F. (2001). Natural and human-mediated factors in the recovery and subsequent expansion of the Purple swamphen Porphyrio porphyrio L. (Rallidae) in the Iberian Peninsula. Biodiversity and Conservation, 10(6), 851-867.

Tammisto, A. (1997). Birds in Mosaics: A Study on the Representation of Birds in the Hellenistic and Romano-Campanian Tessellated Mosaics to the Early Augustan Age. Volume XVIII. Rome: Acta Instituti Romani Finlandiae.

Taylor, B. (1998). Rails, A Guide to the Rails, Crakes, Gallinules and Coots of the World. New Haven, Ст: Yale University Press.

Taylor, P. B. (1996). Family Rallidae (Rails, Gallinules and Coots). In J. D. Hoyo, A. Elliott, \& J. Sargatal (Eds.), Handbook of the Birds of the World-Volume 3 (pp. 108-209). Barcelona: Lynx Edicions.

Toynbee, J. M. C. (1973). Animals in Roman Life and Art. London: Thames and Hudson. 
Trewick, S. A., \& Gibb, G. C. (2010). Vicars, tramps and assembly of the New Zealand avifauna: A review of molecular phylogenetic evidence. Ibis, 152, 226-253.

Vergara, G., \& Ripoll, M. (2002) Action Plan for the conservation of Purple Gallinule (Porphyrio porphyrio). In European Union Action Plans. European Commission, Strasbourg.

Woodford, M. H., \& Rossiter, P. B. (1994). Disease risks associated with wildlife translocation projects. In P. J. S. Olney, G. M. Mace, \& A. T. C. Feistner (Eds.), Creative Conservation (pp. 178-200). Springer Netherlands. 